\title{
What do the parents of children who have chronic pain expect from their first visit to a pediatric chronic pain clinic?
}

\author{
Kathy Reid RN MN NP1,2, Janice Lander RN PhD ${ }^{1}$, Shannon Scott RN PhD ${ }^{1,3}$, Bruce Dick PhD 2,4
}

\begin{abstract}
K Reid, J Lander, S Scott, B Dick. What do the parents of children who have chronic pain expect from their first visit to a pediatric chronic pain clinic? Pain Res Manage 2010;15(3):158-162.
\end{abstract}

BACKGROUND: Chronic pain in childhood is increasingly recognized as a significant clinical problem. Best-practice management of pediatric chronic pain in a multidisciplinary pain clinic involves a variety of treatment modalities. It is important that parents of children treated in these settings understand the different treatment options available for their children. By involving parents more effectively, care providers may more efficiently address unmet treatment needs and improve tailoring of treatment programs aimed at increasing function, reducing pain-related disability and improving quality of life.

OBJECTIVES: To explore the expectations held by parents for their first visit to a pediatric multidisciplinary pain clinic.

METHODS: Fourteen parents completed a paper-based survey exploring their expectations immediately before their first visit to a multidisciplinary pediatric pain clinic in a tertiary care children's hospital.

RESULTS: Responses from parents suggest a clear desire for information about the causes of their child's pain, treatment options available at the pain clinic, effective strategies to enhance children's ability to cope with pain, and the effects of pain on both body and mood. Most parents rated the various treatment options as important for their child. All parents indicated it was very important to have the pain team 'be there' for them. CONCLUSIONS: These findings indicate that parents want more information about chronic pain and treatment options. Pediatric chronic pain clinics have the ability to assist children with chronic pain and their families considerably by providing information about chronic pain and the various treatment options available to them.

Key Words: Adolescents; Children; Chronic pain; Expectations; Parents

\section{Qu'attendent les parents d'enfants souffrant de douleur chronique d'une première visite dans une clinique pédiatrique pour la douleur chronique?}

HISTORIQUE : On reconnaît de plus en plus la douleur chronique chez l'enfant comme un problème clinique important. Dans toute clinique pluridisciplinaire de traitement de la douleur, les pratiques optimales en matière de soulagement des maux chroniques chez l'enfant reposent sur une variété de modalités thérapeutiques. Il est important que les parents d'enfants traités dans ces cliniques comprennent les différentes options offertes à leurs enfants. En faisant participer davantage les parents, les professionnels de la santé peuvent combler plus efficacement les besoins thérapeutiques et mieux individualiser les plans de soins en vue d'améliorer le fonctionnement et la qualité de vie et de réduire l'invalidité causée par la douleur.

OBJECTIF : Analyser les attentes des parents vis-à-vis d'une première consultation dans une clinique pluridisciplinaire pédiatrique de la douleur.

MÉTHODE : Quatorze parents ont répondu à un questionnaire imprimé portant sur leurs attentes immédiatement avant une première consultation dans une clinique pluridisciplinaire pédiatrique de la douleur attachée à un centre de soins tertiaires pour enfants.

RÉSULTATS : Dans leurs réponses, les parents indiquent clairement vouloir être informés des causes de la douleur chez leur enfant, des options thérapeutiques offertes par la clinique, des stratégies efficaces pour aider l'enfant à composer avec la douleur et des effets de cette dernière sur le corps et sur l'humeur. La plupart des parents ont jugées importantes les diverses options thérapeutiques offertes pour leur enfant. Tous les parents ont indiqué accorder une très grande importance au soutien que leur témoigne l'équipe.

CONCLUSIONS : Ces résultats indiquent que les parents souhaitent plus de renseignements au sujet de la douleur chronique et des options thérapeutiques. Les cliniques pluridisciplinaires pédiatriques de la douleur peuvent aider beaucoup les enfants et leurs familles en leur fournissant des renseignements sur la douleur chronique et sur les diverses options thérapeutiques qui leur sont offertes.

\section{TREATMENT EXPECTATIONS OF PARENTS WHOSE CHILDREN ARE REFERRED TO A PEDIATRIC CHRONIC PAIN CLINIC}

Chronic pain in childhood is increasingly recognized as a significant clinical problem that affects multiple domains of the lives of both the child and the family. Between $15 \%$ and $39 \%$ of children are estimated to have chronic pain (1-3). The most common chronic pain complaint is headache, followed by abdominal pain and musculoskeletal pain (4). Up to $50 \%$ of children who report chronic pain indicate multiple sites, most commonly headache and abdominal pain (5). For most children, chronic pain is not debilitating in the long term.
However, for a small percentage of children, pain can be severe and disabling. This can lead to the development of 'pain-associated disability syndrome', which is characterized by severe difficulties with functional abilities regardless of location or cause of pain (6). Affecting between $1 \%$ and $3 \%$ of the pediatric population, children with this syndrome are most likely to be referred to a pediatric multidisciplinary pain clinic (4). Dedicated pediatric chronic pain clinics have been developed in tertiary pediatric hospitals in Canada. Five pediatric chronic pain clinics were reported to serve the Canadian pediatric population in 2007. These clinics each had the capacity to accept between 30 and 80 new referrals annually (7).

${ }^{1}$ Faculty of Nursing, University of Alberta; ${ }^{2}$ Stollery Children's Hospital; ${ }^{3}$ Department of Pediatrics, Faculty of Medicine and Dentistry;

${ }^{4}$ Departments of Anesthesiology and Pain Medicine $\mathcal{E}$ Psychiatry, Faculty of Medicine and Dentistry, University of Alberta, Edmonton, Alberta

Correspondence: Ms Kathy Reid, Stollery Children's Hospital, 1C1.04 8440-112 Street, Edmonton, Alberta T6G 2 G3.

Telephone 780-407-1363, e-mail kathy.reid@albertahealthservices.ca 
Therefore, many Canadian children with disabling chronic pain will go untreated because of the lack of a clinic in their area or because they are not referred.

Chronic pain has the potential to affect many dimensions of the lives of both the child and family. The biopsychosocial approach to chronic pain management attempts to address the many dimensions potentially involved. This approach addresses the biological bases of pain; psychological consequences of pain, and psychological interventions that assist the child and family to understand and cope with the pain; and social consequences of pain, including changes in the child's social relationships and how society's beliefs about pain affect the child (8-10). Pediatric chronic pain clinics use a multidisciplinary approach involving pharmacological management, physical therapy and psychological interventions. This approach assists the child and family to manage the pain and decrease disability. The approach has been found to improve functioning and the child's well-being (11-18). There is good evidence that psychological treatments, including relaxation and cognitive behavioural therapy, are effective for certain chronic pain conditions in children, but more research is needed (19-23).

Few studies have addressed the treatment expectations of parents and children with chronic pain. In a recent commentary, Long and Guite (24) emphasized the importance of this topic. Their commentary addressed the need to develop measures to assess treatment expectations from both a research and a clinical perspective, and argued that treatment expectations of both the child and the parents should be assessed. Carter (25) reported on a small sample of families whose children had chronic pain. Her research found that by the time a child and family were seen at a multidisciplinary pain clinic, they had often seen many specialists and were suffering from 'referral fatigue'. For some parents, a firm diagnosis had not been provided and they were still searching for an organic reason for their child's pain. Families were cautious about disclosing information and felt 'worn down' from their previous medical encounters. Communication encounters between doctors and children was often restricted to specific medical diagnostic questions, without addressing the wider context of pain. Claar and Scharff (26) asked parents an open-ended question before they attended a pain clinic about what they thought would be most helpful if the pain continued. Parents most frequently cited learning to cope with the pain and learning to manage stress. However, a significant number of parents (11\%) and children (17\%) reported that they did not know what to do for their children's pain, and that current therapies for pain were not effective for their children. Research into treatment expectations for complementary therapies for managing chronic pain in children has shown that parents rated these as more likely to be helpful than their children did, but that the expected benefits from both complementary and conventional treatments was low for both the parents and the children (27).

It is important to examine pain and its associated disability within the context of the parent-child relationship. Understanding the treatment expectations of parents will add to the growing knowledge base of factors associated with pediatric chronic pain. The purpose of the present study was to explore the treatment expectations of parents presenting for their first visit to a multidisciplinary pediatric chronic pain clinic.

\section{Sample}

\section{METHODS}

A consecutive sample of parents of children referred to the pediatric multidisciplinary pain clinic at the Stollery Children's Hospital (Edmonton, Alberta) over a four-month period was asked to complete the study questionnaire. Potential participants were required to meet the clinic's referral criteria of chronic pain of at least three months duration, chronic pain as the primary complaint, and chronic pain that affects activities of daily living, school attendance, sleep, quality of life or family functioning. In addition to these criteria, parents were required to be able to speak and read English.

\section{Procedures}

Ethical approval for the present study was obtained from the University of Alberta Health Research Ethics Board. Informed consent was obtained from all participants. Operational approval and administrative support was obtained from the Stollery Children's Hospital, where the Pediatric Chronic Pain Clinic was located. Parents were approached by an assistant and asked to complete the survey while waiting for their appointment in the pain clinic. Participation was voluntary.

To increase anonymity of responding, parents were asked to return the survey in a sealed envelope regardless of whether they decided to participate.

\section{Measures}

Informational needs and treatment expectations were assessed using questions based on previously developed items for complementary and alternative medicine interventions in pediatric chronic pain (27), and from the Pediatric Complex Pain Clinic One-Year Evaluation tool from the Alberta Children's Hospital (Calgary, Alberta). The questions were constructed and reviewed by clinical experts. Parents were asked to rate the importance of informational needs about various aspects of chronic pain and various treatment options. All items were close ended, with a response scale from 1 to 4 . The following response options were available: not important, somewhat important, important or very important. The survey also contained two open-ended questions about other information needs and treatment wishes. In addition, demographic data about the child were collected, including pain location, duration and frequency, and the number of health care professionals who had previously been consulted regarding pain.

\section{RESULTS}

Data were coded and checked for errors. Descriptive data were obtained for all variables (Table 1).

All new referrals to the clinic over a four-month period met the inclusion criteria and were asked to participate $(n=17)$. Fourteen families agreed to participate (82\%). Sample characteristics are presented in Table 1. Children ranged in age from four to 17 years. The child's mother usually completed the survey. The typical chronic pain history could be characterized as frequent and long term (relative to a child's lifespan). The two most common pain sites were the head and abdomen. A physician was the most frequently consulted health professional, and a psychologist was the second most frequently consulted health professional. The ratings chosen by each respondent to all of the questions are presented in Table 2. 


\section{TABLE 1}

\section{Demographic data $(n=14)$}

\begin{tabular}{|c|c|}
\hline \multicolumn{2}{|l|}{ Age of the child, years } \\
\hline Mean \pm SD & $12.85 \pm 3.5$ \\
\hline Range & $4-17$ \\
\hline \multicolumn{2}{|c|}{ Relationship of the respondent to the child, $\mathrm{n}(\%)$} \\
\hline Mother & $12(86)$ \\
\hline Father & 0 \\
\hline Both & $1(7)$ \\
\hline \multicolumn{2}{|l|}{ Duration of pain, $\mathrm{n}(\%)$} \\
\hline$<3$ months & 0 \\
\hline $3-6$ months & 0 \\
\hline $6-12$ months & $2(14)$ \\
\hline $1-2$ years & $2(14)$ \\
\hline$>2$ years & $10(71)$ \\
\hline \multicolumn{2}{|c|}{ Frequency of pain, $\mathrm{n}(\%)$} \\
\hline Daily & $11(79)$ \\
\hline 5-6 days/week & $1(7)$ \\
\hline 2-4 days/week & $1(7)$ \\
\hline 1 day/week & 0 \\
\hline$<1$ day/week & 0 \\
\hline \multicolumn{2}{|l|}{ Pain site/diagnosis, $\mathrm{n}$} \\
\hline Headache & 7 \\
\hline Abdominal pain & 7 \\
\hline Muscular pain & 4 \\
\hline Fibromyalgia & 4 \\
\hline CRPS & 5 \\
\hline Sickle cell disease & 1 \\
\hline Other & 4 \\
\hline \multicolumn{2}{|c|}{ Health professionals previously consulted about pain, $\mathrm{n}$} \\
\hline Physician & 12 \\
\hline Psychologist & 5 \\
\hline Physiotherapist & 3 \\
\hline Naturopath & 3 \\
\hline Acupuncturist & 1 \\
\hline Chiropractor & 1 \\
\hline Massage therapist & 1 \\
\hline
\end{tabular}

Respondents were permitted to make multiple responses. CRPS Complex regional pain syndrome

\section{The need for information}

Information about the cause of the pain and treatments was important or very important to $93 \%$ of respondents. Information about drugs to help the pain was important or very important to $72 \%$ of respondents. Information about ways to cope with the pain, effects of pain on feelings or mood, and effects of pain on the body was very important to all respondents.

\section{Treatment options}

Receiving pain medication, having further medical testing, and getting counselling or psychological help was an important or very important treatment option for $72 \%$ of respondents. Having physiotherapy was important to only $43 \%$ of respondents. Eighty-six per cent of respondents rated reading materials as important, and 64\% rated information sessions as important. Having the pain team be there for them was very important to $93 \%$ of respondents. Having other parents be there for them was important to only $50 \%$ of respondents. Attempts were made to conduct some subanalyses on ratings of importance for responses with adequate sample size (using $\chi^{2}$ analysis). Respondents were grouped based on rating of importance
TABLE 2

Importance of information and treatment options for each respondents

\begin{tabular}{|c|c|c|c|c|c|c|c|c|c|c|c|c|c|c|}
\hline \multirow{2}{*}{$\begin{array}{l}\text { How important is information } \\
\text { about: }\end{array}$} & \multicolumn{14}{|c|}{ Respondents } \\
\hline & 1 & 2 & 3 & 4 & 5 & 6 & 7 & 8 & 9 & & 11 & 12 & & 14 \\
\hline Cause of pain & 4 & 4 & 4 & 4 & 4 & & 4 & 4 & 3 & 3 & 3 & 4 & 4 & 4 \\
\hline Treatments & 4 & 4 & 4 & 4 & 4 & & 4 & 4 & 4 & 4 & 4 & 4 & 4 & 4 \\
\hline Drugs to help the pain & 2 & 4 & 4 & 3 & 2 & & 4 & 3 & 3 & 4 & 3 & 2 & 4 & 3 \\
\hline Ways to cope with the pain & 4 & 4 & 4 & 4 & 4 & 4 & 4 & 4 & 4 & 4 & 4 & 4 & 4 & 4 \\
\hline $\begin{array}{l}\text { Effects of pain on feelings or } \\
\text { mood }\end{array}$ & 4 & 4 & 4 & 4 & 4 & 4 & 4 & 4 & 4 & 4 & 4 & 4 & 4 & 4 \\
\hline Effects of pain on the body & 4 & 4 & 4 & 4 & 4 & 4 & 4 & 3 & 4 & 4 & 4 & 4 & 4 & 4 \\
\hline \multicolumn{15}{|c|}{ How important is each pain treatment: } \\
\hline Receiving pain drugs & 2 & 4 & 4 & 1 & 4 & 1 & 4 & 3 & 3 & 4 & 3 & 2 & 4 & 3 \\
\hline $\begin{array}{l}\text { Receiving additional medical } \\
\text { tests }\end{array}$ & & 4 & 4 & 1 & 4 & 4 & 4 & 2 & 2 & 3 & 2 & 3 & 4 & 3 \\
\hline Having physiotherapy & 3 & 4 & 4 & 4 & 4 & 4 & 4 & 2 & 2 & 2 & 1 & 2 & 3 & 1 \\
\hline $\begin{array}{l}\text { Getting counselling or } \\
\text { psychological help }\end{array}$ & & 4 & 4 & 4 & 4 & 4 & 4 & 2 & 3 & 1 & 3 & 3 & 1 & 3 \\
\hline Getting reading materials & 3 & 4 & 4 & 3 & 4 & 4 & 4 & 1 & 3 & 2 & 4 & 3 & 4 & 3 \\
\hline Attending information sessions & 4 & 4 & 3 & 2 & 3 & 4 & 4 & 2 & 2 & 1 & 4 & 3 & 2 & 4 \\
\hline $\begin{array}{l}\text { Having the pain team be there } \\
\text { for you }\end{array}$ & 4 & 4 & 4 & 4 & 4 & 4 & 4 & 3 & 4 & 4 & 4 & 4 & 4 & 4 \\
\hline $\begin{array}{l}\text { Having other parents be there } \\
\text { for you }\end{array}$ & 3 & 4 & 3 & 1 & 3 & 4 & 4 & 2 & 2 & 1 & 2 & 4 & 2 & 1 \\
\hline
\end{tabular}

(important, not important) and whether they had counselling or physiotherapy to determine whether exposure to the treatment affected ratings of importance. However, at least one of the expected cell frequencies was below the minimum of five, making the $\chi^{2}$ analysis impossible to perform.

The two open-ended questions were left blank on 10 of the surveys. Four completed surveys asked for further information that was very specific to their child's medical conditions, and in one case, a parent asked for information about the physiology of pain. When asked about other treatment options, three completed surveys included requests. One respondent expressed interest in alternative therapies, one queried regarding diagnostic tests available for locating organic etiologies of pain and one asked for information regarding future follow-up.

\section{DISCUSSION}

In the present article, we report the results of a descriptive study of parents' ratings of information and treatments. Respondents reported that it was very important to receive most of the information that would be provided in a pediatric chronic pain clinic. The need and desire for information is a common finding in studies addressing chronic illness and disability.

The findings from the present study indicate that the majority of respondents rated the various therapies available in a pediatric chronic pain clinic as important. However, some did not view all therapies to be important. According to McGrath and Ruskin (28), treatment regimens for chronic pain often comprise the three $\mathrm{P}$ approach - pharmacological, physical and psychological therapy. Parents need to understand the reasons for this multidimensional approach to follow treatment recommendations. Education about the importance of treatment 
approaches and potential treatment outcomes should be provided to parents early in the referral process to help parents appreciate their significance and follow through with recommended treatments.

Over one-half of the respondents in the present study rated receiving additional medical tests as important. They may view additional diagnostic testing as having the potential to uncover an organic explanation for the cause of the pain. Unfortunately, many of these diagnostic tests are expensive and hold little potential for uncovering etiologies of many chronic pain syndromes. Schechter (10) observed that family physicians often continue to investigate the cause of the pain. The family may perceive continued investigation as evidence that a cause has yet to be uncovered, ultimately leading them on a search for new tests and health care professionals willing to order the tests. It is important for health care professionals working with children to know which red flags indicate the need for further clinical investigation and to reassure families that these will be ordered when indicated.

It was not possible to conduct additional analyses on respondents who rated further clinical investigation as important compared with those who did not. Future research should examine how these parents' needs and attitudes influence chronic pain management approaches.

The majority of the children in the present study had lived with chronic pain for longer than two years. An interesting observation was that some very young children experienced chronic pain. For example, one of the children whose parent took part in the study was four years of age.

The sample size of the present study reflects the four-month enrollment of new referrals to a pediatric chronic pain clinic.

\section{REFERENCES}

1. Merlijn VP, Hunfeld JA, van der Wouden JC,

Hazebroek-Kampschreur AA, Passchier J, Koes BW. Factors related to the quality of life in adolescents with chronic pain. Clin J Pain 2006;22:306-15.

2. Roth-Isigkeit A, Thyen U, Stoven H, Schwarzenberger J, Schmucker P. Pain among children and adolescents: Restrictions in daily living and triggering factors. Pediatrics 2005;115:e152-62.

3. Perquin CW, Hazenbroek-Kampschreur A, Hunfeld J, et al. Pain in children and adolescents: A common experience. Pain 2000;87:51-8

4. Eccleston C, Bruce E, Carter B. Chronic pain in children and adolescents. Pediatr Nurs 2006;18:30-3.

5. Kristjansdottir G. Prevalence of pain combinations and overall pain: A study of headache, stomach pain and back pain among school-children. Scand J Soc Med Suppl 1997;25:58-63.

6. Bursch B, Joseph MH, Zeltzer LK. Pain-associated disability syndrome. In: Schechter NL, Berde CB, Yaster M, eds. Pain in Infants, Children and Adolescents, 2nd edn. Philadelphia: Lippincott, Williams \& Wilkins, 2002:841-8.

7. Peng P, Stinson J, Choiniere M, et al. Dedicated multidisciplinary pain management centers for children in Canada: The current status. Can J Anaesth 2007;54:963-8.

8. American Pain Society Pediatric Chronic Pain Advocacy Statement. <http://www.ampainsoc.org> (Accessed on July 20, 2007).

9. Zeltzer LK, Tsao JC, Bursch B, Myers CD. Introduction to the special issue on pain: From pain to pain-associated disability syndrome. J Pediatr Psychol 2006;31:661-6.

10. Schechter NL. Treatment of acute and chronic pain in the outpatient setting. In: Finley GA, McGrath PJ, Chambers C, eds. Bringing Pain Relief to Children: Treatment Approaches. Totowa: Humana Press, 2006:31-58.

11. Connelly M, Schanberg L. Latest developments in the assessment and management of chronic musculoskeletal pain syndromes in children. Curr Opin Rheumatol 2006;18:496-502.
Although small, the sample characteristics suggest that the sample is typical of children with chronic pain across many other studies (29-31). The number of new referrals to this clinic points to issues Canadian children have in gaining access to specialized pediatric chronic pain clinics. If the current estimates of prevalence are accurate, a great need exists to enhance chronic pain management services in Canada. Strategies also need to be developed to make these services available in rural and remote areas of the country, where pediatric chronic pain clinics are unlikely to be available. Furthermore, not all children have access to specialized pediatric chronic pain clinics. This raises questions about the long-term impact of persistent chronic pain on children's development and success stepping forward into adulthood. This is an important topic for future research.

Most respondents in the present study were mothers. This is consistent with what occurs in many pediatrics clinics and research involving children because it is often the mother who brings a child to appointments. The parent who attended the first appointment at our clinic was the one asked to complete the survey.

While the results of the present study are preliminary and are taken from a relatively small sample, our findings highlight many key components that families look for in a chronic pain management program. It is critical that researchers and clinicians who study and work with these children and their families take a true family-centred approach. Much remains to be learned in this important area. We call for an increased focus on understanding and meeting the needs of this clinical population and their family members.
12. Kashikar-Zuck S. Treatment of children with unexplained chronic pain. Lancet 2006;367:380-2.

13. Malleson PN, Connell H, Bennett SM, Eccleston C. Chronic musculoskeletal and other idiopathic pain syndromes. Arch Dis Child 2001;84:189-92.

14. Blecourt A, Preuper H, Van Der Schans C, Groothoff J, Reneman M. Preliminary evaluation of a multidisciplinary pain management program for children and adolescents with chronic musculoskeletal pain. Disabil Rehabil 2008;30:13-20.

15. Popenhagen M. Undertreatment of pain and fears of addiction in pediatric chronic pain patients: How do we stop the problem? J Spec Pediatr Nurs 2006;11:61-7.

16. Walstrom J. The child with chronic pain. J Spec Pediatr Nurs 2004;9:135-8.

17. Howard R. Current status of pain management in children. JAMA 2003;290:2464-9.

18. Matthews E. A snapshot view of the impact of chronic pain on adolescents. Br J Nurs 2002;11:735-44.

19. Eccleston C, Yorke L, Morley S, Williams A, Mastroyannopoulou K. Psychological therapies for the management of chronic and recurrent pain in children and adolescents. Cochrane Database Syst Rev 2003;1:1-33.

20. Damen L, Bruijn J, Koes B, Berger M, Passchier J, Verhagen A. Prophylactic treatment of migraine in children. Part 1. A systematic review of non-pharmacological trials. Cephalgia 2005;26:373-83.

21. McGrath P, Dick B, Unruh A. Psychological and behavioral treatment of pain in children. In: Schechter NL, Berde CB, Yaster M, eds. Pain in Infants, Children and Adolescents, 2nd edn. Philadelphia: Lippincott, Williams \& Wilkins, 2003:303-16.

22. Holden E, Deichmann M, Levy J. Empirically supported treatment in pediatric psychology: Recurrent pediatric headache. J Pediatr Psychol 1999;24:91-109.

23. Walco G, Sterling C, Conte P, Engel R. Empirically supported treatments in pediatric psychology: Disease-related pain. J Pediatr Psychol 1999;24:155-67. 
24. Long A, Guite J. Treatment-related expectations in pediatric chronic pain. <http://childpain.org/ppl/issues/v10n3_2008/v10n3. shtml $>$ (Accessed on January 14, 2010).

25. Carter B. Chronic pain in childhood and the medical encounter: Professional ventriloquism and hidden voices. Qual Health Res 2002;12:28-41.

26. Claar RL, Scharff L. Parent and child perceptions of chronic pain treatments. Child Health Care 2007;36:285-301.

27. Tsao J, Meldrum M, Bursch B, Jacob M, Su C, Zeltzer L. Treatment expectations for CAM interventions in pediatric chronic pain patients and their parents. Evid Based Complement Alternat Med 2005;4:521-7.
28. McGrath P, Ruskin D. Caring for children with chronic pain: Ethical considerations. Paediatr Anaesth 2007;17:505-8.

29. Dell'Api M, Rennick J, Rosmus C. Childhood chronic pain and health care professional interactions: Shaping the chronic pain experiences of children. J Child Health Care 2007;11:269-86.

30. Eccleston C, Malleson P. Managing chronic pain in children and adolescents. BMJ 2003;326:1408-9.

31. Bennett SM, Huntsman E, Lilley CM. Parent perceptions of the impact of chronic pain in children and adolescents. Child Health Care 2000;29:147-59. 


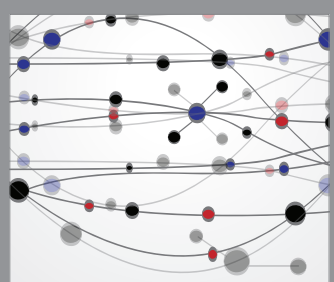

The Scientific World Journal
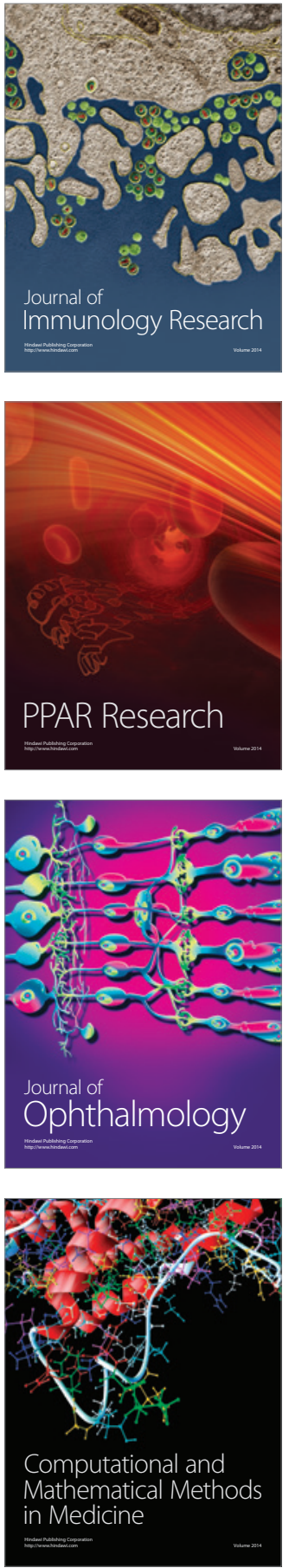

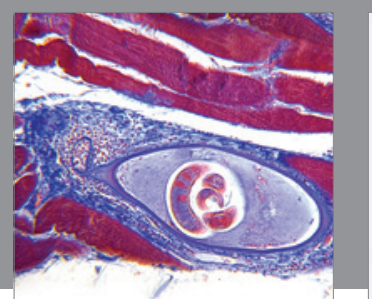

Gastroenterology Research and Practice

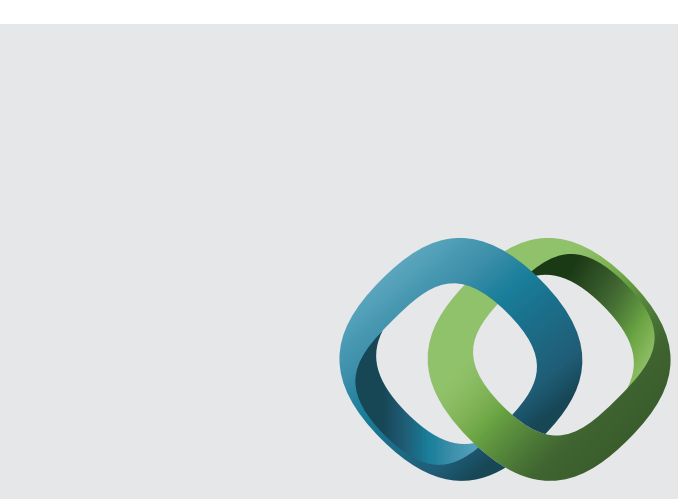

\section{Hindawi}

Submit your manuscripts at

http://www.hindawi.com
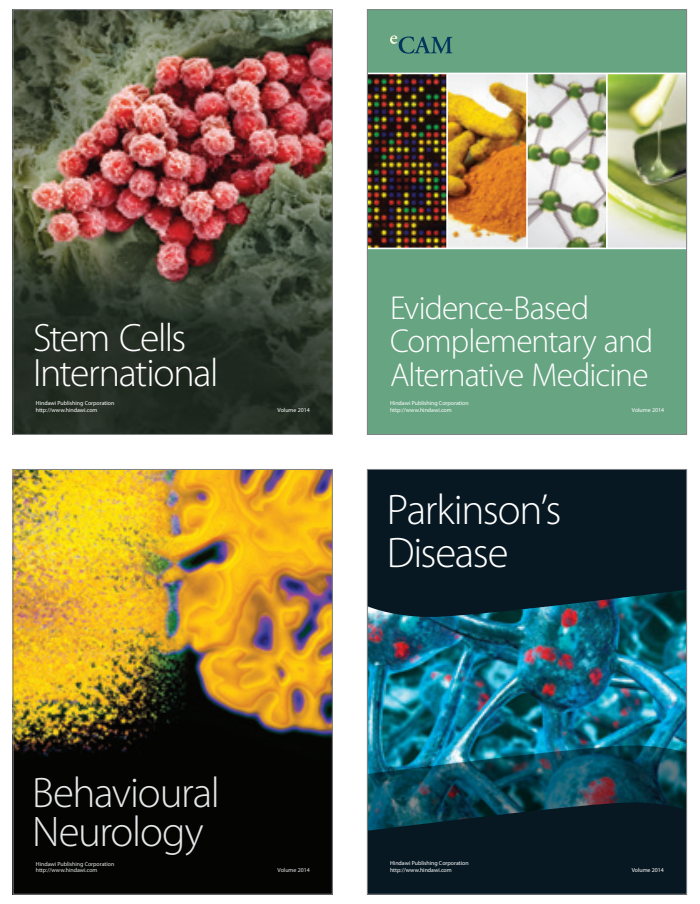
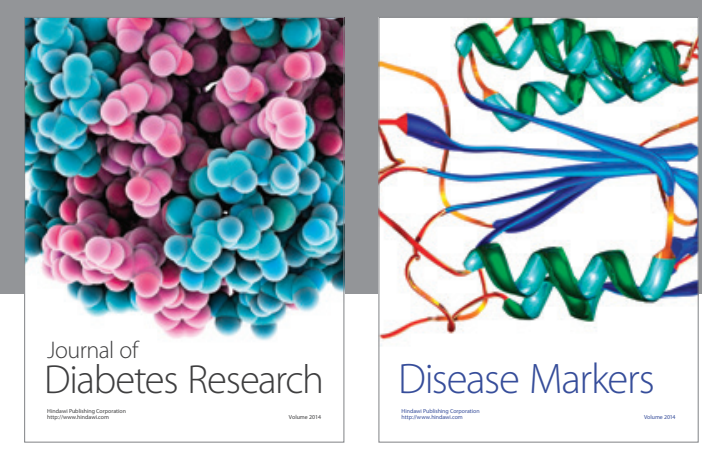

Disease Markers
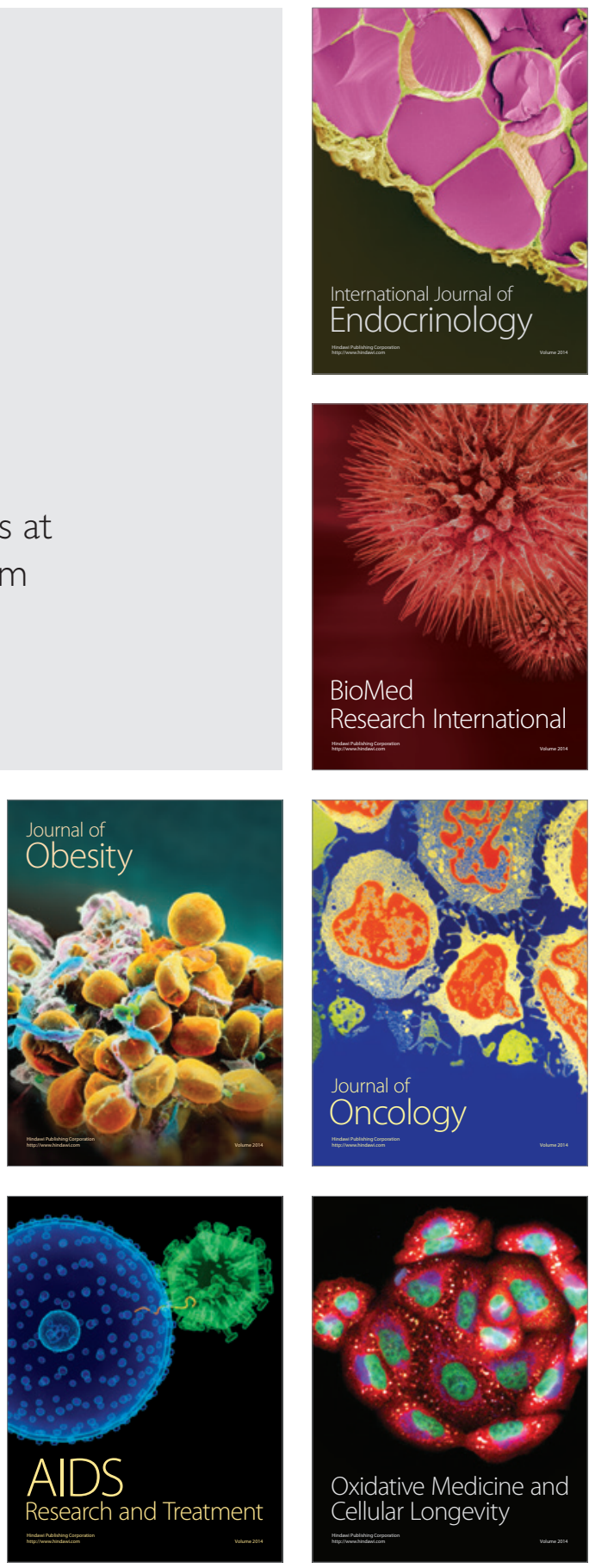